\title{
Analisis Permasalahan Usaha Perikanan di Kecamatan Cibinong, Kabupaten Bogor, Provinsi Jawa Barat
}

\author{
[The Analysis and Issues of Fisheries Business in Cibinong Subdistrict, \\ Bogor District, West Java Province]
}

Egi Dita Aprilia, Nia Nurfitriana, Tatty Yuniarti

Program Studi Penyuluhan Perikanan Politeknik Ahli Usaha Perikanan Jln. Cikaret No. 2 Kecamatan Bogor Selatan Kota Bogor

\begin{abstract}
Abstrak
Kecamatan Cibinong sebagai pusat pertumbuhan ekonomi di Kabupaten Bogor yang memiliki sektor perikanan yang cukup baik, dengan total produksi ikan hias sebesar 25.688 ton dan ikan konsumsi sebesar 1.461 ton. Penelitian bertujuan untuk mengidentifikasi wilayah potensi perikanan, dan menganalisis permasalahan pada sistem produksi, sistem bisnis dan sistem penyuluhan perikanan di Kecamatan Cibinong. Metode yang digunakan berupa penelusuran data skunder dan Participatory Rural Appraisal (PRA) dengan penentuan jumlah responden menggunakan perhitungan slovin. Hasil Penelitian ini berupa perbandingan analisis usaha per segmen perikanan yang terdiri dari Total Biaya Produksi, Pendapatan, Keuntungan, Revenue Cost (R/C), Break Event Point (BEP), Return of Invesment (ROI), dan Payback Periode (PP) serta analisis permasalahan melalui pohon masalah. Segmen-segmen yang terdapat di Kecamatan Cibinong yaitu Segmen pembenihan dan pembesaran ikan konsumsi (lele, nila, dan gurame), budidaya ikan hias (neon tetra dan koki), dan pengolahan hasil perikanan (Kaki naga, abon ikan, pempek, dan krispi kulit ikan) dengan rataan biaya produksi dan kelayakan usaha tertinggi dari keempat segmen perikanan yaitu, terdapat pada pembudidaya ikan hias untuk 3 RTP, Total biaya produksi: RP.1.629.082,-; Pendapatan: Rp. 3.183.333,-; Keuntungan: Rp. 1.553.916 BEP: 563.100; BEP Unit: 356 ekor; PP: 3; R/C: 1,8; ROI: 27,3\%. Pendapatan dan keuntungan terendah terdapat pada segmen pengolahan yang mengolah abon ikan atas nama Titin Z. Permasalahan perikanan yang dapat disimpulkan terdiri dari budidaya perikanan yang memiliki produktivitas rendah, kualitas produk olahan hasil perikanan masih kurang memadai, pendapatan pelaku usaha yang masih belum maksimal, dan dinamika kelompok usaha yang belum dapat berjalan maksimal. Permasalahan tersebut dapat diselesaikan dengan menyusun rencana kerja programa penyuluhan yang akan dilaksanakan.
\end{abstract}

Kata kunci: analisis usaha; metode penyuluhan; permasalahan perikanan

\section{Abstract}

Cibinong District is the center of economic growth in Bogor Regency which has a fairly good fishery sector, with a total production of 25,688 tons of ornamental fish and 1,461 tons of fish consumption. This study aims to identify potential areas for fisheries, production systems, business systems, and fishery extension systems. The method used secondary data tracking and Participatory Rural Appraisal (PRA) by determining the number of respondents using slovin calculations. The results of this study are a comparison of business analysis per fishery segment consisting of Total Production Costs, Revenues, Profits, Revenue Costs (R/C), Break Event Point (BEP), Return of Investment (ROI), and Payback Period (PP) and analysis of the problem through the problem tree. The segments in Cibinong District are the hatchery and rearing segment for consumption of fish (catfish, tilapia, and carp), ornamental fish cultivation (neon tetra and chef), and fishery product processing (dragon feet, shredded fish, pempek, and skin crispy). fish) with the highest average production costs and business feasibility of the four fishery segments, namely, ornamental fish cultivators for 3 RTP, Total production costs: RP.1,629,082,-; Income: Rp. 3.183.333,-; Profit: Rp. 1,553,916 BEP: 563,100; BEP Units: 356 tails; PP: 3; R/C: 1.8; ROI: $27.3 \%$. The lowest income and profits are in the processing segment that processes shredded fish on behalf of Titin $Z$. The fishery problems that can be concluded consist of aquaculture that 
has low productivity, the quality of processed fishery products is still inadequate, the income of business actors is still not maximized, and dynamics business groups that have not been able to run optimally. These problems can be solved by compiling a work plan for the extension program to be implemented.

Keywords: business analysis; extension method; fisheries problems

Penulis Korespondensi

Nia Nurfitriana | nia.adie@gmail.com

\section{PENDAHULUAN}

Kecamatan Cibinong merupakan salah satu pusat pertumbuhan ekonomi di Kabupaten Bogor dan sebagian besar memiliki sumber penghasilan di sektor pertanian termasuk perikanan. Hal ini terbukti dengan total produksi ikan hias dan ikan konsumsi sebesar 25.688 ton dan 1.461 ton (Dinas Perikanan dan Peternakan Kabupaten Bogor 2019). Selain ikan hias, Kabupaten Cibinong menjadikan ikan air tawar seperti lele, gurame, dan nila sebagai salah satu jenis usaha budidaya perikanan yang masyarakat Cibinong geluti. Tidak hanya budidaya perikanan, pengolahan hasil perikanan juga menjadi andalan sumber penghasilan, sehingga analisis usaha pelaku usaha perikanan di Kabupaten Cibinong yang perlu diketahui untuk keberlanjutan usaha yang lebih baik ke depannya.

Pengembangan usaha perikanan yang dilakukan oleh kelompok perikanan memerlukan peranan penyuluh. Penyuluh memerlukan informasi mengenai permasalahan usaha pada kelompok perikanan. Permasalahan usaha dapat diketahui dengan menganalisis usaha kelompok. Selain analisis usaha perikanan, analisis permasalahan yang berkaitan dengan usaha perikanan harus dideskripsikan secara mendetail sehing ga pelaku usaha perikanan dapat mencari solusi terhadap permasalahan yang selama ini terjadi, salah satunya melalui penyuluhan dengan menyusun rencana kerja programa penyuluhan (Putri et al. 2019). Suatu proses yang dilakukan secara terus menerus, sekuat tenaga dan pikiran, memakan waktu dan melelahkan, sampai berdampak pada terjadinya perubahan perilaku yang ditunjukkan oleh penerima manfaat penyuluhan yang menjadi klien penyuluhan disebut juga penyuluhan perikanan (Safrida, Makmur, dan Fachri 2015).

Penyuluhan merupakan kegiatan non formal untuk mendifusikan atau menyampaikan pesan dari penyuluh berupa inovasi perikanan dan kelautan sehingga inovasi tersebut dapat diadopsi oleh sasaran penyuluhan sesuai kebutuhan mereka. Apabila inovasi tersebut telah dapat diterapkan berarti sasaran penyuluhan telah melakukan perubahan 
dalam aspek perilaku baik pengetahuan, sikap, dan keterampilan yang bertujuan supaya hidup mereka dapat lebih sejahtera sehingga mereka dapat mandiri dan mengubah nasibnya sendiri. Tujuan penyuluhan adalah perubahan perilaku sasaran yang mencakup pengetahuan, sikap, dan keterampilan dengan tujuan akhir penyuluhan adalah dapat meningkatkan kesejahteraan hidup yang lebih baik (Mustaqim dan Nuraini 2019). Penelitian bertujuan untuk mengidentifikasi wilayah potensi perikanan, dan menganalisis permasalahan pada sistem produksi, sistem bisnis dan sistem penyuluhan perikanan.

\section{BAHAN DAN METODE}

\section{Lokasi dan Waktu Penelitian}

Penelitian ini dilaksanakan pada tanggal 21 November 2020 hingga 20 Januari 2021. Lokasi penelitian berada di Kecamatan Cibinong, Kabupaten Bogor, Provinsi Jawa Barat.

\section{Jenis dan Metode Pengumpulan Data}

Jenis data yang diambil dalam kegiatan penelitian ini terdiri dari data primer dan data sekunder. Data primer adalah data yang diperoleh langsung melalui teknik wawancara dan observasi dari objek yang diteliti dan berasal dari pembudidaya ikan, pengolah ikan, pemasar produk hasil perikanan, penyuluh perikanan, tokoh masyarakat, dan pemda setempat. Data sekunder ini diperoleh dengan teknik dokumentasi. Sumber data sekunder diperoleh dari: Biro Pusat Statistik (BPS), Kantor Dinas Perikanan dan Peternakan Kabupaten Bogor, Laporan Tahunan Dinas Perikanan dan Peternakan Kabupaten Bogor serta studi literatur dan internet, berupa data sumber daya manusia perikanan, sumber daya alam dan sarana penunjang.

\section{Responden}

Sampel responden pada penelitian ini menggunakan ditentukan menggunakan metode Slovin. Desa sampel ditentukan dengan cara berkonsultasi dengan penyuluh perikanan Kecamatan Cibinong untuk menentukan desa yang memiliki potensi perikanan (metode purposive sampling). Desa dijadikan sampel sebanyak $50 \%$ dari total keseluruhan populasi desa yang berpotensi dan ditambah 1 desa potensi perikanan. Kecamatan Cibinong memiliki 8 desa yang terdapat potensi perikanan dengan pertimbangan keadaan aktual serta potensi wilayah dan kegiatan usaha perikanan pada desa tersebut.

Desa sampel pada penelitian ini adalah: 1) Desa Pabuaran, 2) Desa Tengah, 3) Desa Pakansari, 4) Desa Karadenan, dan 5) Desa Harapan Jaya. Desa tersebut dipilih dengan alasan dalam kondisi pandemik ini selain untuk 
mempermudah akses karena jarak yang berdekatan dan juga terdapat 105 rumah tangga produksi/perikanan (RTP) yang tergabung dalam kelompok perikanan yang masih aktif dan dibina oleh penyuluh Kecamatan Cibinong. Rumus Slovin penentuan jumlah responden ditentukan sebagai berikut :

$$
\begin{gathered}
n=\frac{N}{1+N(e)^{2}} \\
n=\frac{105}{1+105(20 \%)^{2}} \\
n=\frac{105}{5,2} \\
n=20
\end{gathered}
$$

Responden adalah RTP yang tergabung dalam dari kelompok pembudidaya, dan kelompok pengolah. Responden digunakan untuk mengidentifikasi permasalahan dan usaha perikanan. Berikut adalah karakteristik responden pada penelitian dapat dilihat pada Tabel 1.

\section{Metode Analisis}

\section{Analisis Aktivitas Usaha Perikanan}

Analisis usaha merupakan pemeriksaan keuangan untuk mengetahui sampai di mana keberhasilan yang telah dicapai selama usaha itu berkembang. Pengusaha membuat perhitungan dan menentukan tindakan untuk memperbaiki dan meningkatkan keuntungan dalam usahanya (Harmono 2015). Sebagai contoh beberapa hal yang dianalisis dalam analisis sistem usaha perikanan antara lain Total Biaya
Produksi, Pendapatan, Keuntungan, Revenue Cost (R/C), Break Event Point (BEP), Return of Invesment (ROI), dan Payback Periode (PP). Adapun rumus analisis yang digunakan dalam penelitian ini sebagai berikut:

\section{a. Total Biaya Produksi}

= Biaya Tetap + Biaya Variabel

\section{b. Pendapatan}

$=$ Total Produksi $\times$ Harga Jual $/ \mathrm{kg}$

c. Keuntungan/ siklus = Penjualan - Total Biaya Produksi Keuntungan/ tahun = Keuntungan/siklus X Frekuensi/ tahun

d. $\mathrm{R} / \mathrm{C}$

$$
\text { RC Ratio }=\frac{\text { Penjualan }}{\text { Total Biaya }}
$$

\section{e. Break Event Point (BEP)}

$$
\begin{gathered}
\operatorname{BEP}(\mathrm{Rp})=\frac{\text { Biaya Tetap }}{1-\frac{\text { Biaya Variabel }}{\text { Penjualan }}} \\
\operatorname{BEP}(\text { Unit })=\frac{\text { Biaya Tetap }}{\text { Harga Jual- } \frac{\text { Biaya Variabel }}{\text { jumlah produksi }}}
\end{gathered}
$$

\section{f. ROI}

$$
\text { ROI }=\frac{\text { Laba Usaha }}{\text { Investasi }} \times 100 \%
$$

\section{g. Payback Period (PP)}

$$
P P=\frac{\text { Investasi }}{\text { Keuntungan }}
$$

\section{Analisis Permasalahan}

Analisis permasalahan yang dilakukan dalam penelitian ini bertujuan untuk menganalisis masalah usaha perikanan yang terdapat di Kecamatan Cibinong, Kabupaten Bogor dengan 
Tabel 1. Karakteristik Responden

\begin{tabular}{|c|c|c|c|c|c|c|c|}
\hline No & Nama & $\begin{array}{l}\text { Alamat } \\
\text { Desa }\end{array}$ & $\begin{array}{l}\text { Umur } \\
\text { (Tahun) }\end{array}$ & $\begin{array}{l}\text { Pendidikan } \\
\text { Terakhir }\end{array}$ & $\begin{array}{l}\text { Kelompok } \\
\text { Perikanan }\end{array}$ & $\begin{array}{l}\text { Pengalaman } \\
\text { (Tahun) }\end{array}$ & $\begin{array}{c}\text { Luas } \\
\text { Usaha } \\
\text { (m2) }\end{array}$ \\
\hline 1. & Siti Maryam & Tengah & 49 & D4 & Otslan & 2 & 150 \\
\hline 2. & Daryati & Tengah & 36 & SMA & Otslan & 2 & 150 \\
\hline 3. & $\begin{array}{l}\text { Eka Sylviani } \\
\text { A }\end{array}$ & Tengah & 48 & $\mathrm{~S} 1$ & Otslan & 2 & 150 \\
\hline 4. & Abdul Kohar & Tengah & 52 & SD & $\begin{array}{l}\text { Permata } \\
\text { Jaya }\end{array}$ & 8 & 200 \\
\hline 5. & $\begin{array}{l}\text { Rudi } \\
\text { Anggoro }\end{array}$ & Tengah & 25 & SMA & Tirta Lestari & 5 & 200 \\
\hline 6. & Abdul Rojak & Tengah & 49 & SD & Mitra Karya & 7 & 1000 \\
\hline 7. & $\begin{array}{l}\text { Tian } \\
\text { Ardiansyah }\end{array}$ & Tengah & 48 & SMA & $\begin{array}{l}\text { Rawa } \\
\text { Genis }\end{array}$ & 5 & 500 \\
\hline 8. & $\begin{array}{l}\text { Entjon Boedi } \\
\mathrm{P}\end{array}$ & Pabuaran & 49 & SMA & Darma Tirta & 9 & 50 \\
\hline 9. & $\begin{array}{l}\text { Filayati } \\
\text { Prahesti }\end{array}$ & Pabuaran & 26 & S1 & Darma Tirta & 9 & 50 \\
\hline 10. & Ema Renita & Pabuaran & 42 & SMEA & $\begin{array}{l}\text { Mina } \\
\text { Sejahtera }\end{array}$ & 9 & 50 \\
\hline 11. & Nyai Faridah & Pabuaran & 38 & SD & $\begin{array}{l}\text { Mina } \\
\text { Sejahtera }\end{array}$ & 9 & 50 \\
\hline 12. & Titin Z & Pabuaran & 49 & SD & $\begin{array}{l}\text { Mina } \\
\text { Sejahtera }\end{array}$ & 9 & 50 \\
\hline 13. & Kaimudin & Pabuaran & 48 & S2 & $\begin{array}{l}\text { Sejahtera } \\
\text { Mina } \\
\text { Lestari }\end{array}$ & 5 & 2500 \\
\hline 14. & Amin & Pakansari & 39 & SMA & $\begin{array}{l}\text { Cahay } \\
\text { Mandiri }\end{array}$ & 13 & 500 \\
\hline 15. & Sukirman & Pakansari & 51 & SMP & $\begin{array}{l}\text { Cahaya } \\
\text { Mandiri }\end{array}$ & 13 & 500 \\
\hline 16. & Edy Sofa & Pakansari & 40 & SMA & Kelasta & 7 & 100 \\
\hline 17. & Rifai $A$ & Karadenan & 44 & S1 & $\begin{array}{l}\text { Amanah } \\
\text { Catfish } \\
\text { Farm }\end{array}$ & 1 & 100 \\
\hline 18. & Yuswar & Karadenan & 45 & SMA & $\begin{array}{l}\text { Amana } \\
\text { Catfish } \\
\text { Farm }\end{array}$ & 1 & 200 \\
\hline 19 & Tris Kismiati & Karadenan & 56 & SMA & Hanada & 4 & 150 \\
\hline 20 & M. Ilyas & $\begin{array}{l}\text { Harapan } \\
\text { Jaya }\end{array}$ & 56 & SMP & Citra Karya & 6 & 3000 \\
\hline
\end{tabular}

menggunakan Pohon Masalah (Problem Tree). Analisis pohon masalah di sini dilakukan dengan membentuk pola pikir yang lebih terstruktur mengenai komponen sebab akibat yang berkaitan dengan masalah yang telah diprioritaskan.
HASIL DAN PEMBAHASAN

\section{Hasil}

Analisis Usaha Perikanan

Rataan Analisis Usaha per segmen usaha perikanan Perhitungan analisis usaha pada segmen pembesaran ikan konsumsi yaitu ikan lele, nila, dan 
Tabel 2. Rataan Biaya Usaha Pembesaran Ikan Kosumsi

\begin{tabular}{|c|c|c|c|c|c|c|c|c|}
\hline No & Nama & Investasi (Rp) & $\begin{array}{l}\text { Biaya } \\
\text { Penyusutan } \\
\text { /Siklus }\end{array}$ & $\begin{array}{c}\text { Biaya } \\
\text { Variabel } \\
\text { /Siklus (Rp) }\end{array}$ & $\begin{array}{c}\text { Biaya } \\
\text { Tetap/Siklus } \\
\text { (Rp) }\end{array}$ & $\begin{array}{c}\text { Biaya } \\
\text { Produksi } \\
\text { /Siklus (Rp) }\end{array}$ & $\begin{array}{l}\text { Pendapatan } \\
\text { /Siklus (Rp) }\end{array}$ & Keunt। \\
\hline 1 & Abdul Rojak & 91.405 .000 & 273.416 & 20.000 .000 & 1.290 .250 & 21.290 .250 & 33.970 .000 & 12.6 \\
\hline 2 & M.llyas & 91.405 .000 & 273.416 & 40.000 .000 & 1.590 .250 & 41.590 .250 & 71.375 .000 & 32.7 \\
\hline 3 & Rifai A & 1.110 .000 & 68.499 & 3.900 .000 & 475.000 & 4.375 .500 & 5.434 .000 & $1 . C$ \\
\hline 4 & Yuswar & 8.110 .000 & 76.833 & 4.550 .000 & 500.500 & 5.050 .500 & 8.151 .000 & 3.1 \\
\hline 5 & Abdul Kohar & 31.275 .000 & 187.916 & 3.800 .000 & 1.021 .666 & 4.821 .666 & 6.850 .000 & 2.C \\
\hline 6 & Tian A & 51.355 .000 & 161472 & 28.000 .000 & 1.268 .833 & 1.268 .833 & 70.000 .000 & 40.7 \\
\hline & JUMLAH & 274.660 .000 & 1.041 .552 & $100.250,000$ & 6.146 .499 & 78.396.999 & 195.780 .000 & 92.3 \\
\hline & RATAAN & 45.776 .666 & 173.592 & 16.708 .333 & $1.024 .416,5$ & 13.066 .166 .5 & 32.630 .000 & 15.3 \\
\hline
\end{tabular}

Tabel 3. Rataan Biaya Usaha Budidaya Ikan Hias

\begin{tabular}{lccrrrrrr}
\hline No & Nama & $\begin{array}{c}\text { Investasi } \\
\text { (Rp) }\end{array}$ & $\begin{array}{c}\text { Biaya } \\
\text { Penyusutan } \\
\text { /Siklus }\end{array}$ & $\begin{array}{c}\text { Biaya } \\
\text { Variabel } \\
\text { /Siklus (Rp) }\end{array}$ & $\begin{array}{c}\text { Biaya } \\
\text { Tetap/Siklus } \\
\text { (Rp) }\end{array}$ & $\begin{array}{c}\text { Biaya } \\
\text { Produksi } \\
\text { /Siklus (Rp) }\end{array}$ & $\begin{array}{c}\text { Pendapatan } \\
\text { /Siklus (Rp) }\end{array}$ & Keuntungan \\
\hline 1 & Amin & 4.590 .000 & 45.249 & 908 & 435.749 & 1.343 .749 & 2.550 .000 & 1.206 .250 \\
2 & Sukirman & 5.150 .000 & 50.416 & 1.135 .000 & 451.249 & 1.586 .249 & 3.000 .000 & 1.413 .750 \\
3 & Rudi A & 3.470 .000 & 34.916 & 1.552 .500 & 404.749 & 1.957 .249 & 4.000 .000 & 2.042 .750 \\
\hline & JUMLAH & $\mathbf{1 3 . 2 1 0 . 0 0 0}$ & $\mathbf{1 3 0 . 6 2 6}$ & $\mathbf{3 , 5 9 5 , 0 0 0}$ & $\mathbf{1 , 2 9 1 , 7 4 7}$ & $\mathbf{4 , 8 8 7 , 2 4 7}$ & $\mathbf{9 . 5 5 0 . 0 0 0}$ & $\mathbf{4 , 6 6 1 , 7 5 0}$ \\
& RATAAN & $\mathbf{4 . 4 0 3 . 3 3 3}$ & $\mathbf{4 3 . 5 4 2}$ & $\mathbf{1 . 9 8 . 3 3 3}$ & $\mathbf{4 3 0 . 5 8 2}$ & $\mathbf{1 . 6 2 9 . 0 8 2}$ & $\mathbf{3 . 1 8 3 . 3 3 3}$ & $\mathbf{1 . 5 5 3 . 9 1 6}$ \\
\hline
\end{tabular}

gurame yang dijalankan oleh 6

pembudidaya dapat dilihat pada Tabel 2.

Pada Tabel 2 menjelaskan bahwa rataan pendapatan dan rataan keuntungan dari usaha pembesaran ikan konsumsi oleh 6 (enam) Rumah Tangga Perikanan (RTP) sebesar Rp. 32.630.000,dan Rp. 15.397.499,-. Pendapatan dan tertinggi diperoleh Bapak M. Ilyas dengan komoditas ikan lele sebesar Rp. 71.357.000,- dan Rp. 32.784.750.-Perhitungan analisis usaha pada segmen budidaya ikan hias yaitu ikan koki dan neon tetra yang dijalankan oleh 3 pembudidaya dapat dilihat pada Tabel 3.
Tabel 3 menjelaskan rataan pendapatan dan rataan keuntungan dari usaha pembesaran ikan hias oleh 3 (tiga) Rumah Tangga Perikanan (RTP) sebesar Rp 3.183.333,- dan Rp 1.533.916,-Pendapatan dan keuntungan tertinggi diperoleh Bapak Rudi A dengan komoditas ikan koki sebesar Rp. 4.000.000,- dan Rp. 2.042.750. Perhitungan analisis usaha pada segmen pembenihan ikan konsumsi yaitu ikan yang dijalankan oleh 1 pembudidaya dapat dilihat pada Tabel 4. 
Tabel 4. Rataan Biaya Pembenihan Ikan Konsumsi

\begin{tabular}{ccccccccr}
\hline No & Nama & $\begin{array}{c}\text { Investasi } \\
(\mathbf{R p})\end{array}$ & $\begin{array}{c}\text { Biaya } \\
\text { Penyusutan } \\
\text { /Siklus }\end{array}$ & $\begin{array}{c}\text { Biaya } \\
\text { Variabel } \\
\text { /Siklus (Rp) }\end{array}$ & $\begin{array}{c}\text { Biaya } \\
\text { Tetap/Siklus } \\
(\mathbf{R p})\end{array}$ & $\begin{array}{c}\text { Biaya } \\
\text { Produksi } \\
\text { /Siklus (Rp) }\end{array}$ & $\begin{array}{c}\text { Pendapatan } \\
\text { /Siklus (Rp) }\end{array}$ & Keuntungan \\
\hline 1 & Kaimudin & 10.355 .000 & 99.583 & 1.310 .000 & 869.583 & 2.179 .583 & 3.750 .000 & 1.570 .416 \\
\hline JUMLAH & $\mathbf{1 0 . 3 5 5 . 0 0 0}$ & $\mathbf{9 9 . 5 8 3}$ & $\mathbf{1 . 3 1 0 . 0 0 0}$ & $\mathbf{8 6 9 . 5 8 3}$ & $\mathbf{2 . 1 7 9 . 5 8 3}$ & $\mathbf{3 . 7 5 0 . 0 0 0}$ & $\mathbf{1 . 5 7 0 . 4 1 6}$ \\
\hline
\end{tabular}

Tabel 5. Rataan Biaya Pengolahan Hasil Perikanan

\begin{tabular}{|c|c|c|c|c|c|c|c|c|}
\hline No & Nama & Investasi (Rp) & $\begin{array}{l}\text { Biaya } \\
\text { Penyusutan } \\
\text { /Siklus }\end{array}$ & $\begin{array}{c}\text { Biaya } \\
\text { Variabel } \\
\text { /Siklus (Rp) }\end{array}$ & $\begin{array}{c}\text { Biaya } \\
\text { Tetap/Siklus } \\
\text { (Rp) }\end{array}$ & $\begin{array}{c}\text { Biaya } \\
\text { Produksi } \\
\text { /Siklus (Rp) }\end{array}$ & $\begin{array}{l}\text { Pendapatan } \\
\text { /Siklus (Rp) }\end{array}$ & Keuntungan \\
\hline 1 & Entjon B & 53.220 .000 & 410.747 & 1.310 .500 & 1.510 .747 & 2.821 .247 & 4.800 .000 & 1.978 .753 \\
\hline 2 & Filayati & 42.785 .000 & 286.83 & 1.210 .500 & 1.386 .830 & 2.587 .330 & 4.200 .000 & 1.612 .670 \\
\hline 3 & Edy Sofa & 81.865 .000 & 567.469 & 3.794 .000 & 2.017 .469 & 5.811 .469 & 9.000 .000 & 3.188 .531 \\
\hline 4 & Ema Renita & 45.4550 .000 & 320.583 & 3.099 .500 & 1.420 .583 & 4.520 .083 & 5.400 .000 & 879.917 \\
\hline 5 & Titin Z & 35.315 .000 & 276.916 & 1.599 .500 & 1.376 .916 & 2.976 .416 & 4.320 .000 & 1.343 .584 \\
\hline 6 & Nyai Faridah & 40.315 .000 & 296.749 & 1.699 .500 & 1.296 .794 & 2.996 .294 & 4.800 .000 & 1.803 .706 \\
\hline 7 & Siti Maryam & 60.860 .000 & 392.222 & 5.552 .000 & 1.542 .222 & 5.706 .222 & 10.500 .000 & 4.793 .777 \\
\hline 8 & Daryati & 50.860 .000 & 350.555 & 4.409 .000 & 1.500 .555 & 5.909 .555 & 8.400 .000 & 2.490 .444 \\
\hline 9 & Eka S & 40.860 .000 & 308.888 & 3.386 .000 & 1.458 .888 & $4.844,888$ & 7.350 .000 & 2.505 .111 \\
\hline 10 & Tris Kismiati & 54.940 .000 & 295.111 & 4.736 .000 & 4.736 .000 & 6.2 .81 .111 & 7.500 .000 & 1.218 .888 \\
\hline & JUMLAH & 506.475 .000 & 3.506 .070 & 30.796 .500 & 18.247 .004 & 44.454 .615 & 66.270 .000 & 31.815 .381 \\
\hline & RATAAN & 50.647 .500 & 350.607 & 3.079 .650 & $1.824 .700,44$ & $4.445 .461,5$ & 6.627 .000 & 3.181 .538 \\
\hline
\end{tabular}

Pada Tabel. 3 menjelaskan bahwa rataan pendapatan dan rataan keuntungan yang digunakan dalam usaha pembenihan ikan konsumsi sebesar Rp. 3.750.000,- dan Rp. 1.570.416. Sedangkan, pada Tabel 4, rataan pendapatan dan rataan keuntungan yang digunakan dalam usaha pengolahan hasil perikanan sebesar Rp. 6.627.000,dan Rp3.181.538. Perhitungan analisis usaha pada segmen pengolahan hasil perikanan yaitu kaki naga, abon ikan, pempek, dan krispi kulit ikan yang dijalankan oleh 10 orang pengolah dapat dilihat pada Tabel 5.

Rataan biaya yang digunakan dalam usaha pengolahan hasil perikanan dapat dilihat pada Tabel 4. Rataan pendapatan dan keuntungan yang didapatkan dari usaha pengolahan hasil perikanan adalah sebesar Rp. 6.627.000,dan Rp. 3.181.538. Pendapatan dan keuntungan tertinggi diperoleh Ibu Siti Maryam dengan produk pempek sebesar Rp. 10.500.000,- dan Rp. 4.793.777,-Perhitungan kelayakan usaha segmen 


\begin{tabular}{|ccccccc}
\hline \multicolumn{7}{|c}{ Tabel 6. Rataan kelayakan usaha Pembesaran Ikan Konsumsi } \\
\hline NO & NAMA & BEP (Rp) & BEP (UNIT) & PP (Bulan) & R/C & ROI (\%) \\
\hline 1 & Abdul Rojak & 3.072 .024 & 160 & 7,2 & 1,6 & 14 \\
2 & M.llyas & 3.383 .511 & 197 & 2,7 & 1,7 & 35 \\
3 & Rifai A & 1.639 .655 & 88 & 6,7 & 1,2 & 14 \\
4 & Yuswar & 1.112 .222 & 59 & 3,6 & 1,6 & 30 \\
5 & Abdul Kohar & 2.270 .370 & 91 & 15,4 & 1,4 & 6 \\
6 & Tian A & 3.965 .103 & 60 & 1,2 & 1,3 & 70 \\
\hline & JUMLAH & $\mathbf{1 5 . 4 4 2 . 8 8 5}$ & $\mathbf{6 5 5}$ & $\mathbf{3 6 , 8}$ & $\mathbf{8 , 8}$ & $\mathbf{1 6 9}$ \\
\hline & RATAAN & $\mathbf{2 . 5 7 3 . 8 1 4}$ & $\mathbf{1 0 9 , 1 6}$ & $\mathbf{6 , 1 3}$ & $\mathbf{1 , 4 6}$ & $\mathbf{2 8 , 1 6}$ \\
\hline
\end{tabular}

Tabel 7. Rataan Kelayakan Usaha Budidaya Ikan Hias

\begin{tabular}{clccccc}
\hline NO & NAMA & BEP (RP) & $\begin{array}{c}\text { BEP } \\
\text { (UNIT) }\end{array}$ & PP (Bulan) & R/C & ROI (\%) \\
\hline 1 & Amin & 508.999 & 451 ekor & 3,8 & 1,8 & 20 \\
2 & Sukirman & 618.15 & 484 ekor & 3,6 & 1,8 & 20 \\
3 & Rudi & 562.152 & 132 ekor & 1,6 & 2 & 50 \\
\hline & JUMLAH & $\mathbf{1 , 6 8 9 , 3 0 1}$ & $\mathbf{1 . 0 6 7}$ & $\mathbf{9}$ & $\mathbf{5 , 6}$ & $\mathbf{9 0}$ \\
\hline & RATAAN & $\mathbf{5 6 3 , 1 0 0}$ & $\mathbf{3 5 5 . 6}$ & $\mathbf{3}$ & $\mathbf{1 , 8}$ & $\mathbf{3 0}$ \\
\hline
\end{tabular}

pembesaran ikan konsumsi oleh 6 orang pembudidaya dapat dilihat pada Tabel 6 .

Dari hasil rataan analisis kelayakan usaha pembesaran ikan konsumsi pada Tabel 5, menyatakan bahwa usaha budidaya tersebut layak untuk diteruskan. Hal tersebut dapat dilihat dari Revenue Cost Ratio dengan nilai ratarata 1,4 yang dapat diartikan setiap Rp. 1 yang dikeluarkan dapat menghasilkan keuntungan sebanyak Rp. 0,40. Rataan Payback Period (PP) adalah sebesar 6 tahun 13 bulan. Hal tersebut dapat diartikan bahwa biaya investasi dapat dikembalikan dalam 6 tahun 13 bulan. Perhitungan kelayakan usaha segmen budidaya ikan hias oleh 3 orang pembudidaya dapat dilihat pada Tabel 7 .

Dari rataan analisis kelayakan usaha pembesaran ikan hias pada Tabel 6 , menyatakan bahwa usaha budidaya tersebut layak untuk diteruskan. Hal tersebut dapat dilihat dari Revenue Cost Ratio dengan nilai rata-rata 1,8 yang dapat diartikan setiap Rp.1 yang dikeluarkan dapat menghasilkan keuntungan sebanyak Rp.0,80. Rataan Payback Period (PP) adalah sebesar 3 tahun. Hal tersebut dapat diartikan bahwa biaya investasi dapat dikembalikan dalam 3 tahun. Perhitungan kelayakan 
Tabel 8. Rataan Kelayakan Usaha Pembenihan Ikan Konsumsi

\begin{tabular}{ccccccc}
\hline NO & NAMA & BEP (RP) & BEP (UNIT) & PP (Bulan) & R/C & ROI (\%) \\
\hline 1 & Kaimudin & 1.317 .550 & 905.815 ekor & 6,5 & 1,7 & 15 \\
\hline & JUMLAH & $\mathbf{1 . 3 1 7 . 5 5 0}$ & $\mathbf{9 0 5 . 8 1 5}$ & $\mathbf{6 . 5}$ & $\mathbf{1 , 7}$ & $\mathbf{1 5}$ \\
\hline
\end{tabular}

Tabel 9. Rataan Kelayakan Usaha Pengolahan Hasil Perikanan

\begin{tabular}{|c|c|c|c|c|c|c|}
\hline NO & NAMA & BEP (RP) & $\begin{array}{c}\text { BEP } \\
\text { (UNIT) }\end{array}$ & PP (Bulan) & $R / C$ & $\begin{array}{l}\text { ROI } \\
(\%)\end{array}$ \\
\hline 1 & Entjon B & 2.078 .115 & 139 & 2.2 & 1,7 & 70 \\
\hline 2 & Filayati & 1.926 .152 & 129 & 2,2 & 1,6 & 60 \\
\hline 3 & Edy Sofa & 3.478 .394 & 232 & 2,1 & 1,5 & 50 \\
\hline 4 & Ema Renita & 3.334 .556 & 222 & 4,3 & 1,1 & 19 \\
\hline 5 & Titin Z & 2.151 .431 & 119 & 2,1 & 1,4 & 40 \\
\hline 6 & Nyai Faridah & 1.995 .868 & 125 & 1,8 & 1,6 & 60 \\
\hline 7 & Siti Maryam & 3.212 .962 & 93 & 1 & 1,8 & 80 \\
\hline 8 & Daryati & 3.126 .157 & 90 & 1,7 & 1.4 & 40 \\
\hline 9 & Eka S & 2.701 .646 & 77 & 1,3 & 1,5 & 50 \\
\hline 10 & Tris Kismiati & 4.175 .975 & 297 & 3,7 & 1.1 & 19 \\
\hline \multicolumn{2}{|r|}{ JUMLAH } & 29.181 .256 & 1.523 & 22,4 & 14,7 & 485 \\
\hline \multicolumn{2}{|r|}{ RATAAN } & $2.918 .125,6$ & 152,3 & 2,24 & 1,47 & 48,5 \\
\hline
\end{tabular}

usaha segmen pembenihan ikan konsumsi oleh 1 orang pembudidaya dapat dilihat pada Tabel 8.

Dari rataan analisis kelayakan usaha pembenihan ikan konsumsi pada Tabel 7, usaha budidaya tersebut layak untuk diteruskan. Hal tersebut dapat dilihat dari Revenue Cost Ratio dengan nilai rata-rata 1,7 yang dapat diartikan setiap Rp. 1 yang dikeluarkan dapat menghasilkan keuntungan sebanyak Rp. 0,70. Rataan Payback Period (PP) adalah sebesar 6 tahun 5 Bulan. Hal tersebut dapat diartikan bahwa biaya investasi dapat dikembalikan dalam 6 tahun 5 bulan. Perhitungan kelayakan usaha segmen pengolahan hasil perikanan oleh 10 orang pembudidaya dapat dilihat pada Tabel 9.

Dari rataan analisis kelayakan usaha pengolahan hasil perikanan pada Tabel 8, menyatakan bahwa usaha budidaya tersebut layak untuk diteruskan. Hal tersebut dapat dilihat dari Revenue Cost Ratio dengan nilai rata-rata 1,47 yang dapat diartikan setiap Rp.1 yang dikeluarkan dapat menghasilkan keuntungan sebanyak Rp.0,47. Sedangkan, rataan Payback Period (PP) adalah sebesar 2 tahun 2 bulan yang artinya bahwa biaya investasi dapat dikembalikan dalam 2 tahun 2 bulan. 
Tabel 10. Perumusan masalah

\begin{tabular}{|c|c|}
\hline MASALAH UMUM & MASALAH KHUSUS \\
\hline Produktivitas rendah & 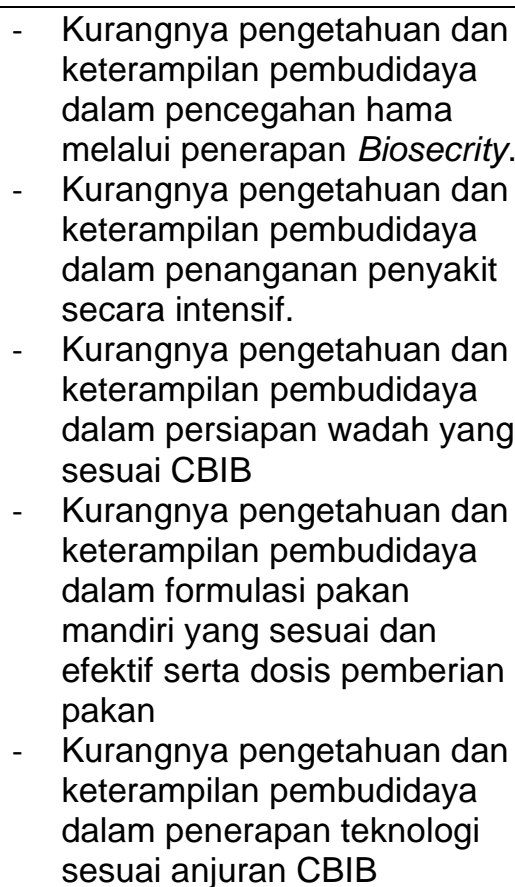 \\
\hline $\begin{array}{l}\text { Mutu produk hasil } \\
\text { olahan kurang terjamin }\end{array}$ & $\begin{array}{l}\text { Kurangnya pengetahuan } \\
\text { pengolah mengenai } \\
\text { penerapan sanitasi higiene. } \\
\text { - } \text { Kurangnya pengetahuan } \\
\text { pengolah mengenai } \\
\text { penerapan GMP (Good } \\
\text { Manufacturing Product) }\end{array}$ \\
\hline $\begin{array}{l}\text { Pendapatan belum } \\
\text { maksimal }\end{array}$ & $\begin{array}{l}\text { - Kurangnya informasi jaringan } \\
\text { pemasaran. } \\
\text { - } \quad \text { kurangnya Pengetahuan } \\
\text { mengenai pengembangan } \\
\text { variasi produk. }\end{array}$ \\
\hline $\begin{array}{l}\text { Dinamika kelompok } \\
\text { belum berjalan } \\
\text { maksimal }\end{array}$ & $\begin{array}{l}\text { - } \quad \text { kurangnya kesadaran pelaku } \\
\text { utama akan pentingnya relasi } \\
\text { dalam kelompok perikanan. }\end{array}$ \\
\hline
\end{tabular}

\section{Analisis Permasalahan}

Analisis permasalahan yang dilakukan dengan menggunakan Analisis Pohon (Tree Analysis). Analisis tersebut mengenai aspek teknis, ekonomi, dan social. Dari analisis pohon masalah maka dapat dirumuskan masalah menjadi dua bagian yaitu masalah umum dan masalah khusus yang dapat dilihat pada
Tabel 10. Adapun penentuan uji prioritas masalah berdasarkan rumusan masalah yang telah disepakati menggunakan tabel prioritas (Tabel 11).

Setelah permasalahan yang ada di Kecamatan Cibinong, Kabupaten Bogor dirumuskan, tujuan umum dan tujuan khusus ditetapkan, sehingga permasalahan tersebut dapat tertangani. Pene- 
tapan tujuan khusus dan umum per bidang perikanan yang dapat dilihat pada Tabel 12.

Dalam rangka pencapaian tujuan programa sebagaimana acuan kegiatan penyuluhan di Kecamatan Cibinong, Kabupaten Bogor, sehingga mampu mengembangkan dan membangun sektor perikanan di wilayah kecamatan tersebut. Penyusunan rencana kerja berfungsi untuk memudahkan dalam mengatasi semua permasalahan yang ada.

Tabel 11. Uji Prioritas Masalah

\begin{tabular}{|c|c|c|c|c|c|c|}
\hline \multirow{2}{*}{ No } & \multirow{2}{*}{ Akar masalah } & \multicolumn{3}{|c|}{ Nilai Skor (1-3) } & \multirow{2}{*}{ Jmlh } & \multirow{2}{*}{$\begin{array}{l}\text { Prioritas } \\
\text { Kegiatan }\end{array}$} \\
\hline & & $\mathbf{G}$ & $\mathbf{M}$ & $\mathbf{P}$ & & \\
\hline \multirow[t]{2}{*}{1.} & Kurangnya pengetahuan dan & & & & & \\
\hline & $\begin{array}{l}\text { keterampilan pembudidaya dalam } \\
\text { pencegahan hama melalui penerapan } \\
\text { Biosecurity. }\end{array}$ & 3 & 2 & 3 & 8 & 3 \\
\hline 2. & $\begin{array}{l}\text { Kurangnya pengetahuan dan } \\
\text { keterampilan pembudidaya dalam } \\
\text { penanganan penyakit secara intensif. }\end{array}$ & 3 & 3 & 3 & 9 & 1 \\
\hline 3. & $\begin{array}{l}\text { Kurangnya pengetahuan dan } \\
\text { keterampilan pembudidaya dalam } \\
\text { persiapan wadah yang sesuai CBIB }\end{array}$ & 2 & 2 & 1 & 4 & 9 \\
\hline \multirow[t]{2}{*}{4.} & Kurangnya pengetahuan dan & & & & & \\
\hline & $\begin{array}{l}\text { keterampilan pembudidaya dalam } \\
\text { formulasi pakan mandiri yang sesuai dan } \\
\text { efektif serta dosis pemberian pakan }\end{array}$ & 3 & 2 & 3 & 8 & 5 \\
\hline \multirow[t]{2}{*}{5.} & Kurangnya pengetahuan dan & & & & & \\
\hline & $\begin{array}{l}\text { keterampilan pembudidaya dalam } \\
\text { penerapan teknologi sesuai anjuran } \\
\text { CBIB }\end{array}$ & 3 & 1 & 2 & 6 & 8 \\
\hline 6. & $\begin{array}{l}\text { Kurangnya pengetahuan pengolah } \\
\text { mengenai penerapan sanitasi higiene. }\end{array}$ & 3 & 3 & 3 & 9 & 2 \\
\hline 7. & $\begin{array}{l}\text { Kurangnya pengetahuan pengolah } \\
\text { mengenai penerapan GMP (Good } \\
\text { Manufacturing Product) }\end{array}$ & 3 & 2 & 3 & 8 & 4 \\
\hline 8. & $\begin{array}{l}\text { Kurangnya pengetahuan mengenai } \\
\text { pengembangan variasi produk }\end{array}$ & 2 & 1 & 1 & 4 & 7 \\
\hline 9 & $\begin{array}{l}\text { Kurangnya informasi jaringan } \\
\text { pemasaran. }\end{array}$ & 2 & 2 & 1 & 5 & 6 \\
\hline 10. & $\begin{array}{l}\text { Kurangnya kesadaran pelaku utama } \\
\text { akan pentingnya relasi dalam kelompok } \\
\text { perikanan. }\end{array}$ & 2 & 1 & 2 & 5 & 10 \\
\hline
\end{tabular}

Keterangan:

a. Gawat (G): Maksudnya merupakan besar/ kecilnya akibat atau kerugian bagi pelaku utama. ( 1 = tidak gawat, 2 = cukup gawat, 3 = sangat gawat)

b. Mendesak (M) : Adanya ketersediaan waktu bagi pemecahan masalah tertentu. Bila masalah tersebut tidak dapat ditunda lagi berarti semakin mendesak. ( 1 = tidak mendesak, 2 = cukup mendesak, 3 = sangat mendesak)

c. Penyebaran $(P)$ : Merata atau hanya parsial saja masalah tersebut muncul, semakin merata berarti penyebarannya semakin tinggi.

d. $(1$ = tidak merata, 2 = parsial, $3=$ sangat merata $)$ 
Tabel 12. Penetapan tujuan umum dan tujuan khusus

\begin{tabular}{|c|c|c|c|}
\hline No & Bidang & TUJUAN UMUM & TUJUAN KHUSUS \\
\hline 1 & $\begin{array}{l}\text { Budidaya } \\
\text { Perikanan }\end{array}$ & Meningkatkan produktivitas & 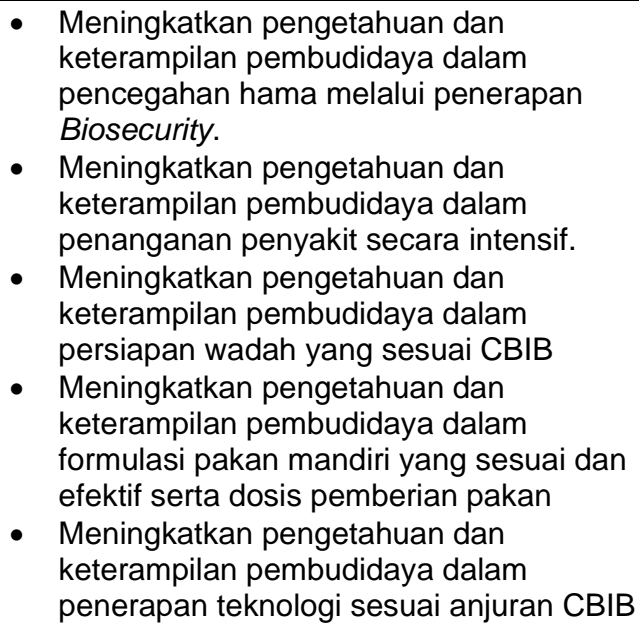 \\
\hline 2 & $\begin{array}{l}\text { Pengolahan } \\
\text { Hasil } \\
\text { Perikanan }\end{array}$ & $\begin{array}{l}\text { Meningkatkan Mutu produk } \\
\text { hasil olahan } \\
\text { Meningkatkan }\end{array}$ & $\begin{array}{l}\text { Meningkatkan pengetahuan pengolah } \\
\text { mengenai penerapan sanitasi higiene. } \\
\text { Meningkatkan pengetahuan pengolah } \\
\text { mengenai penerapan GMP (Good } \\
\text { Manufacturing Product) }\end{array}$ \\
\hline 3 & Ekonomi & $\begin{array}{l}\text { Memaksimalkan } \\
\text { pendapatan }\end{array}$ & $\begin{array}{l}\text { - Kurangnya informasi jaringan pemasaran. } \\
\text { - kurangnya Pengetahuan mengenai } \\
\text { pengembangan variasi produk }\end{array}$ \\
\hline 4 & Penyuluhan & $\begin{array}{l}\text { Meningkatkan fungsi } \\
\text { kelompok melalui } \\
\text { peningkatan dinamika } \\
\text { kelompok. }\end{array}$ & $\begin{array}{l}\text { - Meningkatkan pengetahuan akan } \\
\text { pentingnya relasi di dalam kelompok } \\
\text { perikanan }\end{array}$ \\
\hline
\end{tabular}

Tabel 13. Rencana Kerja Penyuluhan Perikanan

\begin{tabular}{|c|c|c|c|c|c|c|c|c|}
\hline No & Masalah & Kegiatan & Tujuan & Metode & Volume Waktu & Sasaran & $\begin{array}{r}\text { Biaya } \\
(\text { Rp000) }\end{array}$ & $\begin{array}{c}\text { Pihak } \\
\text { Terkait } \\
\end{array}$ \\
\hline 1 & $\begin{array}{l}\text { Kurangnya } \\
\text { pengetahuan } \\
\text { dan } \\
\text { keterampilan } \\
\text { pembudidaya } \\
\text { dalam } \\
\text { pencegahan } \\
\text { hama melalui } \\
\text { penerapan } \\
\text { Biosecrity. }\end{array}$ & $\begin{array}{l}\text { Sosialisasi } \\
\text { tentang } \\
\text { pencegahan } \\
\text { dan } \\
\text { penanggulang } \\
\text { an hama } \\
\text { sesuai CBIB }\end{array}$ & $\begin{array}{l}\text { Meningkatkan } \\
\text { pengetahuan } \\
\text { dan } \\
\text { keterampilan } \\
\text { dalam } \\
\text { pencegahan } \\
\text { dan } \\
\text { penanggulang } \\
\text { an hama dan }\end{array}$ & $\begin{array}{l}\text { Anjangsana/Pertem } \\
\text { uan kelompok }\end{array}$ & 3 kali Maret & $\begin{array}{l}\text { Pelaku } \\
\text { utama/pelak } \\
\text { u usaha di } \\
\text { Kecamatan } \\
\text { Cibinong }\end{array}$ & 100 & $\begin{array}{l}\text { Kepala } \\
\text { Desa/Ketu } \\
\text { a RW }\end{array}$ \\
\hline 2 & $\begin{array}{l}\text { Kurangnya } \\
\text { pengetahuan } \\
\text { dan } \\
\text { keterampilan } \\
\text { pembudidaya } \\
\text { dalam } \\
\text { penanganan } \\
\text { penyakit } \\
\text { secara } \\
\text { intensif. }\end{array}$ & $\begin{array}{l}\text { Sosialisasi } \\
\text { tentang } \\
\text { penanganan } \\
\text { penyakit } \\
\text { secara intensif } \\
\end{array}$ & $\begin{array}{l}\text { Meningkatkan } \\
\text { pengetahuan } \\
\text { dan } \\
\text { keterampilan } \\
\text { mengenai } \\
\text { penerapan } \\
\text { sanitasi dan } \\
\text { hygiene }\end{array}$ & $\begin{array}{l}\text { Anjangsana/Pertem } \\
\text { uan kelompok }\end{array}$ & 3 kali Maret & $\begin{array}{l}\text { Pelaku } \\
\text { utama/pelak } \\
\text { u usaha di } \\
\text { Kecamatan } \\
\text { Cibinong }\end{array}$ & 100 & $\begin{array}{l}\text { Kepala } \\
\text { Desa/Ketu } \\
\text { a RW }\end{array}$ \\
\hline
\end{tabular}


Tabel 13. Rencana Kerja Penyuluhan Perikanan (Lanjutan)

\begin{tabular}{|c|c|c|c|c|c|c|c|c|}
\hline No & Masalah & Kegiatan & Tujuan & Metode & Volume Waktu & Sasaran & $\begin{array}{c}\text { Biaya } \\
(\text { Rp000) }\end{array}$ & $\begin{array}{c}\text { Pihak } \\
\text { Terkait }\end{array}$ \\
\hline 3 & $\begin{array}{l}\text { Kurangnya } \\
\text { pengetahuan } \\
\text { dan } \\
\text { keterampilan } \\
\text { pembudidaya } \\
\text { dalam } \\
\text { persiapan } \\
\text { wadah yang } \\
\text { sesuai CBIB }\end{array}$ & $\begin{array}{l}\text { Sosialisasi } \\
\text { tentang teknis } \\
\text { persiapan } \\
\text { wadah yang } \\
\text { sesuai CBIB }\end{array}$ & $\begin{array}{l}\text { Meningkatkan } \\
\text { pengetahuan } \\
\text { dan } \\
\text { keterampilan } \\
\text { mengenai } \\
\text { persiapan } \\
\text { wadah yang } \\
\text { baik }\end{array}$ & $\begin{array}{l}\text { Anjangsana/Pertem } \\
\text { uan kelompok }\end{array}$ & 3 kali Maret & $\begin{array}{l}\text { Pelaku } \\
\text { utama/pelak } \\
\text { u usaha di } \\
\text { Kecamatan } \\
\text { Cibinong }\end{array}$ & 100 & $\begin{array}{l}\text { Kepala } \\
\text { Desa/Ketu } \\
\text { a RW }\end{array}$ \\
\hline 4 & $\begin{array}{l}\text { Kurangnya } \\
\text { pengetahuan } \\
\text { dan } \\
\text { keterampilan } \\
\text { pembudidaya } \\
\text { dalam } \\
\text { formulasi } \\
\text { pakan mandiri } \\
\text { yang sesuai } \\
\text { dan efektif } \\
\text { serta dosis } \\
\text { pemberian } \\
\text { pakan }\end{array}$ & $\begin{array}{l}\text { Sosialisasi dan } \\
\text { pendampingan } \\
\text { tentang } \\
\text { pemberian } \\
\text { pakan sesuai } \\
\text { dosis } \\
\text { i }\end{array}$ & $\begin{array}{l}\text { Meningkatkan } \\
\text { pengetahuan } \\
\text { dan } \\
\text { keterampilan } \\
\text { dalam } \\
\text { pemberian } \\
\text { pakan sesuai } \\
\text { dengan dosis }\end{array}$ & $\begin{array}{l}\text { Anjangsana/Pertem } \\
\text { uan kelompok }\end{array}$ & 2 kali Maret & $\begin{array}{l}\text { Pelaku } \\
\text { utama/pelak } \\
\text { u usaha di } \\
\text { Kecamatan } \\
\text { Cibinong }\end{array}$ & 100 & $\begin{array}{l}\text { Kepala } \\
\text { Desa/Ketu } \\
\text { a RW }\end{array}$ \\
\hline 5 & $\begin{array}{l}\text { Kurangnya } \\
\text { pengetahuan } \\
\text { dan } \\
\text { keterampilan } \\
\text { pembudidaya } \\
\text { dalam } \\
\text { penerapan } \\
\text { teknologi } \\
\text { sesuai } \\
\text { anjuran CBIB }\end{array}$ & $\begin{array}{l}\text { Sosialisasi } \\
\text { tentang Cara } \\
\text { Budidaya Ikan } \\
\text { Yang Baik } \\
\text { (CBIB) }\end{array}$ & $\begin{array}{l}\text { Meningkatkan } \\
\text { pengetahuan } \\
\text { dan } \\
\text { keterampilan } \\
\text { para } \\
\text { pembudidaya } \\
\text { dalam kegiatan } \\
\text { budidaya } \\
\text { sesuai dengan } \\
\text { CBIB }\end{array}$ & $\begin{array}{l}\text { Anjangsana/Pertem } \\
\text { uan kelompok }\end{array}$ & 3 kali April & $\begin{array}{l}\text { Pelaku } \\
\text { utama/pelak } \\
\text { u usaha di } \\
\text { Kecamatan } \\
\text { Cibinong }\end{array}$ & 100 & $\begin{array}{l}\text { Kepala } \\
\text { Desa/Ketu } \\
\text { a RW }\end{array}$ \\
\hline 6 & $\begin{array}{l}\text { Kurangnya } \\
\text { pengetahuan } \\
\text { pengolah } \\
\text { mengenai } \\
\text { penerapan } \\
\text { sanitasi } \\
\text { higiene. }\end{array}$ & $\begin{array}{l}\text { Sosialisasi } \\
\text { tentang teknis } \\
\text { penerapan } \\
\text { sanitasi dan } \\
\text { higiene }\end{array}$ & $\begin{array}{l}\text { Meningkatkan } \\
\text { pengetahuan } \\
\text { dan } \\
\text { keterampilan } \\
\text { tentang teknis } \\
\text { penerapan } \\
\text { sanitasi dan } \\
\text { hygine }\end{array}$ & $\begin{array}{l}\text { Anjangsana/Pertem } \\
\text { uan kelompok }\end{array}$ & 2 kali April & $\begin{array}{l}\text { Pelaku } \\
\text { utama/pelak } \\
\text { u usaha di } \\
\text { Kecamatan } \\
\text { Cibinong }\end{array}$ & 100 & $\begin{array}{l}\text { Kepala } \\
\text { Desa/Ketu } \\
\text { a RW }\end{array}$ \\
\hline 7 & $\begin{array}{l}\text { Kurangnya } \\
\text { pengetahuan } \\
\text { pengolah } \\
\text { mengenai } \\
\text { penerapan } \\
\text { GMP (Good } \\
\text { Manufacturing } \\
\text { Product) } \\
\end{array}$ & $\begin{array}{l}\text { Sosialisasi } \\
\text { tentang teknis } \\
\text { mengenai } \\
\text { penerapan } \\
\text { GMP (Good } \\
\text { Manufacturing } \\
\text { Product) }\end{array}$ & $\begin{array}{l}\text { Meningkatkan } \\
\text { pengetahuan } \\
\text { dan } \\
\text { keterampilan } \\
\text { tentang teknis } \\
\text { penerapan } \\
\text { GMP }\end{array}$ & $\begin{array}{l}\text { Anjangsana/Pertem } \\
\text { uan kelompok }\end{array}$ & 2 kali April & $\begin{array}{l}\text { Pelaku } \\
\text { utama/pelak } \\
\text { u usaha di } \\
\text { Kecamatan } \\
\text { Cibinong }\end{array}$ & 100 & $\begin{array}{l}\text { Kepala } \\
\text { Desa/Ketu } \\
\text { a RW }\end{array}$ \\
\hline 8 & $\begin{array}{l}\text { Kurangnya } \\
\text { informasi } \\
\text { jaringan } \\
\text { pemasaran. } \\
\\
\end{array}$ & $\begin{array}{l}\text { Mendampingi } \\
\text { pelaku utama } \\
\text { dan pelaku } \\
\text { usaha } \\
\text { perikanan } \\
\text { dalam proses } \\
\text { pemasaran } \\
\end{array}$ & $\begin{array}{l}\text { Memperluas } \\
\text { area } \\
\text { pemasaran }\end{array}$ & $\begin{array}{l}\text { Anjangsana/Pertem } \\
\text { uan kelompok }\end{array}$ & 2 kali April & $\begin{array}{l}\text { Pelaku } \\
\text { utama/pelak } \\
\text { u usaha di } \\
\text { Kecamatan } \\
\text { Cibinong }\end{array}$ & 100 & $\begin{array}{l}\text { Kepala } \\
\text { Desa/Ketu } \\
\text { a RW }\end{array}$ \\
\hline 9 & $\begin{array}{l}\text { kurangnya } \\
\text { Pengetahuan } \\
\text { mengenai } \\
\text { pengembanga } \\
\mathrm{n} \text { variasi } \\
\text { produk. }\end{array}$ & $\begin{array}{l}\text { Sosialisasi } \\
\text { tentang teknis } \\
\text { mengenai } \\
\text { apengembanga } \\
\mathrm{n} \text { variasi } \\
\text { produk }\end{array}$ & $\begin{array}{l}\text { Meningkatkan } \\
\text { pengetahuan } \\
\text { dan } \\
\text { keterampilan } \\
\text { tentang teknis } \\
\text { mengenai } \\
\text { pengembanga } \\
\text { n variasi } \\
\text { produk }\end{array}$ & $\begin{array}{l}\text { Anjangsana/Pertem } \\
\text { uan kelompok }\end{array}$ & 2 kali Mei & $\begin{array}{l}\text { Pelaku } \\
\text { utama/pelak } \\
\text { u usaha di } \\
\text { Kecamatan } \\
\text { Cibinong }\end{array}$ & 100 & $\begin{array}{l}\text { Kepala } \\
\text { Desa/Ketu } \\
\text { a RW }\end{array}$ \\
\hline
\end{tabular}


Tabel 13. Rencana Kerja Penyuluhan Perikanan (Lanjutan)

\begin{tabular}{|c|c|c|c|c|c|}
\hline Tujuan & Metode & Volume Waktu & Sasaran & $\begin{array}{c}\text { Biaya } \\
\text { (Rp000) }\end{array}$ & $\begin{array}{c}\text { Pihak } \\
\text { Terkait } \\
\end{array}$ \\
\hline $\begin{array}{l}\text { leningkatkan } \\
\text { əngetahuan } \\
\text { <an } \\
\text { əntingnya } \\
\text { :lasi dalam } \\
\text { əlompok } \\
\text { ərikanan }\end{array}$ & $\begin{array}{l}\text { Anjangsana/Pertem } \\
\text { uan kelompok }\end{array}$ & 2 kali Mei & $\begin{array}{l}\text { Pelaku } \\
\text { utama/pelak } \\
\text { u usaha di } \\
\text { Kecamatan } \\
\text { Cibinong }\end{array}$ & 100 & $\begin{array}{l}\text { Kepala } \\
\text { Desa/Ketu } \\
\text { a RW }\end{array}$ \\
\hline
\end{tabular}

\section{Pembahasan}

Hasil analisis usaha perikanan di Kecamatan Cibinong, Kabupaten Bogor dapat dijelaskan bahwa usaha perikanan yang berada di lokasi tersebut masih dapat memberikan keuntungan untuk pelaku usaha perikanan. Terdapat permasalahan usaha budidaya perikanan yaitu memiliki produktivitas rendah. Permasalahan usaha pengolahan yaitu kualitas produk olahan hasil perikanan masih kurang memadai. Permasalahan umum adalah pendapatan pelaku usaha yang masih belum maksimal, dan dinamika kelompok usaha yang belum dapat berjalan maksimal. Analisis permasalahan usaha perikanan bermanfaat untuk menghasilkan rekomendasi bagi pembuat kebijakan yaitu pemerintah pusat dan daerah serta penyuluh perikanan untuk bersama-sama bersinergi membantu pelaku usaha perikanan sehingga menyelesaikan permasalahannya (Apriliani, Kurniawan, dan Hikmah 2017).

Permasalahan budidaya perikanan berupa produktivitas yang rendah kerap kali dialami oleh pembudidaya ikan tradisional. Beberapa faktor yang berperan pada rendahnya produktivitas budidaya perikanan antara lain faktor di antaranya jumlah benih ikan yang ditebar, daya tahan ikan terhadap penyakit, daya tahan ikan hingga siap untuk dipanen kemudian dipasarkan (Muhammad Ramadhan dan Trilaksana 2019). Beberapa kegiatan yang dapat digunakan untuk meningkatkan produktivitas budidaya perikanan di antaranya adalah mengoptimalkan potensi yang ada, perlu adanya transfer teknologi dalam pengembangan ikanikan yang berpotensi untuk dibudidayakan agar kesejahteraan dan pembangunan daerah khususnya berbasis perikanan dapat tercapai (Huwoyon dan Gustiano 2013).

Permasalahan usaha pengolahan ikan adalah kualitas produk olahan ikan yang masih kurang memadai. Kualitas produk olahan ikan sangat dipengaruhi oleh mutu bahan baku perikanan. Bahan baku perikanan bersifat high perishable food atau bahan pangan yang sangat mudah rusak memerlukan treatment 
pendinginan agar terjaga mutunya. Pendinginan dilakukan pada saat ikan keluar dari air, sortasi, perlakuan pembersihan ikan, proses produksi hingga pasca produksi olahan ikan (pada produk olahan berkadar air tinggi). Kemunduran mutu ikan dipengaruhi oleh komposisi kimia ikan segar, cara mematikan ikan serta treatment penyimpanan ikan segar. Mutu ikan segar tidak dapat diperbaiki tetapi dapat dipertahankan dengan penanganan ikan yang tepat (Yuniarti et al. 2021). Prinsip ini harus diketahui oleh pengolah ikan. Minimnya pengetahuan tentang kondisi kritis bahan baku perikanan, sanitasi higiene produksi pengolahan ikan dan cara pengolahan ikan yang baik menyebabkan produk olahan ikan bernilai rendah (Zidhane, Yuniarti, dan Nurmalia 2020).

Sanitasi dan higiene pada produksi olahan ikan kerap kali menjadi permasalahan klasik pada pengolahan ikan tradisional. Sanitasi dan higiene perilaku masyarakat dalam memproduksi olahan ikan menjadi titik kritis yang sering ditemukan ketika RTP mengajukan persyaratan sertifikasi PIRT dari Dinas kesehatan kota/kabupaten. Usaha yang dilakukan oleh para penyuluh antara lain dengan mendampingi pelaku usaha perikanan dalam melaksanakan Cara Produksi Pangan yang Baik (CPPB), sehingga dapat meningkatkan pengetahuan, sikap dan keterampilan mengenai
CPPB (Junita et al. 2020). Permasalahan umum perikanan yaitu pendapatan para pelaku usaha atau RTP yang masih belum maksimal. Permasalahan ini dapat disebabkan oleh beberapa hal seperti faktor produktivitas lahan, produktivitas tenaga kerja dan produktivitas modal (Madrin Takbir, Budiyanto 2017). Strategi peningkatan pendapatan pelaku usaha perikanan yang dapat dilakukan oleh penyuluh yaitu meningkatkan kompetensi pembudidaya dilakukan dengan cara mengefektifkan penyuluhan secara partisipatif, memperbesar intensitas penyuluhan dengan pendekatan kelompok, pendekatan pluralistik (keterpaduan) penyuluh PNS/petugas, penyuluh swadaya dan penyuluh swasta), berorientasi pada masa depan dan berkelanjutan (Kustiari et al. 2017).

Permasalahan dominan lain pada usaha perikanan di Kecamatan Cibinong adalah dinamika kelompok usaha yang belum berjalan maksimal. Dinamika bekerja sama dalam kelompok tani (dalam hal ini adalah kelompok usaha perikanan), perlu dibangun bersama antar anggota kelompok dan pengurus. Hal ini tidak mudah, karena kelompok terdiri dari anggota yang mempunyai pendapat berbeda berdasarkan latar belakangnya. Perbedaan ini terkadang menimbulkan konflik. Konflik yang tidak segera diselesaikan mengakibatkan suasana kelompok menjadi tidak kondusif 
untuk melakukan usaha. Penyebabnya adalah melemahnya hubungan antara anggota, keterasingan, mudah marah/ tersinggung dan lain-lain. Pada akhirnya konflik tersebut mengakibatkan pemborosan energi, menurunnya saling percaya dan ketergantungan kepada anggota lainnya, kurangnya kerja sama antar anggota dan terganggunya tujuan usaha kelompok. Diperlukan kerja sama di antara anggota dan pengurus, yaitu melalui pembagian tugas yang baik antara pengurus dan anggota kelompok (Untajana 2011).

Keempat permasalahan perikanan dimasukkan pada rencana kerja programa penyuluhan sebagai dasar untuk membuat perencanaan materi, metode, dan langkah-langkah penyuluhan. UU No. 16 tahun 2016 Tentang sistem penyuluhan pertanian, peternakan, perikanan dan kehutanan, mengamanatkan Peran Penyuluh semakin strategis dalam memfasilitasi proses pemberdayaan petani/pelaku usaha perikanan dan keluarganya. Penyuluh perikanan mengemban tugas menyelaraskan kebutuhan pelaku usaha/RTP baik Pokdakan maupun Poklahsar dengan program Kementerian Kelautan dan Perikanan (Choeronawati dan Rochman 2021)

Kegiatan penyuluhan perikanan pada dasarnya bertujuan untuk meningkatkan pendapatan mereka melalui peningkatan produktivitas hasil budidaya baik itu budidaya air tawar, air payau maupun air laut. Peningkatan pendapatan dalam artian meningkatkan kesejahteraan secara swadaya atau mandiri dengan usaha mereka sendiri melalui perubahan perilaku baik itu pengetahuan, sikap, dan keterampilan. Perubahan perilaku dapat terwujud karena adanya adopsi terhadap inovasi baru di bidang budidaya perikanan, setelah sasaran penyuluhan dapat mengadopsi inovasi tersebut tahap selanjutnya mereka menyebarkan atau mendifusikan inovasi baru yang telah berhasil diadopsi dari sasaran penyuluhan kepada sasaran penyuluhan lainnya. Berbagai inovasi baru di bidang aquaculture di antaranya bioflok, resirkulasi untuk lingkungan, rekayasa genetik terutama rekayasa DNA, vaksin berbagai jenis penyakit ikan dan kandungan nutrisi melalui pakan bahan baku lokal (Nurfitriana, Sabariah, dan Aulia 2020).

Penyuluhan perikanan bertujuan untuk mengubah perilaku sasaran penyuluhan melalui adopsi sebuah inovasi baik itu budidaya, pengolahan, dan penangkapan. Metode dan teknik penyuluhan bertujuan untuk memberikan berbagai alternatif solusi dari permasalahan yang ada yang direkomendasikan melalui programa penyuluhan. Purnomo et al. (2018) pendekatan metode penyuluhan dapat bersifat persuasif yang artinya bahwa penyuluh 
perikanan dalam melaksanakan tugasnya harus mampu meyakinkan khalayaknya, sehingga mereka merasa tertarik dan yakin terhadap hal-hal yang akan disampaikan, edukatif yang artinya bahwa penyuluh perikanan harus bersikap dan berperilaku sebagai pendidik yang dengan penuh kesabaran dan ketekunan membimbing sasarannya, dan komunikatif yang artinya bahwa penyuluh perikanan harus mampu berkomunikasi dan menciptakan iklim serta suasana sedemikian rupa, sehingga tercipta suatu pembicaraan atau komunikasi yang bersifat akrab, terbuka, dan timbal balik.

Peranan pelaku usaha juga tidak kalah penting, selain peranan penyuluh. Hanan (2015) menjelaskan bahwa tujuan penyuluhan jangka panjang adalah terjadi peningkatan taraf hidup masyarakat dalam hal ini pelaku usaha perikanan. Peranan pelaku usaha yang perlu dilakukan antara lain :

a. Better Fisheries, mau dan mampu mengubah cara-cara usaha perikanan yang lebih baik,

b. Better Business, berusaha yang lebih menguntungkan, mau dan mampu menjauhi para pengijon, lintah darat, dan melakukan teknis pemasaran yang benar,

c. Better living, hidup lebih baik dengan mampu menghemat, tidak berfoyafoya dan setelah berlangsungnya masa panen, bisa menabung, beker- ja sama memperbaiki higiene lingkungan, dan mampu mencari alternatif lain dalam hal usaha, misal mendirikan industri rumah tangga yang lain dengan mengikutsertakan keluarganya guna mengisi dan mengoptimalkan tenaga, pemikiran, peluang pasar, ide kreatif yang dikembangkan.

\section{SIMPULAN DAN SARAN \\ Simpulan}

1. Analisis Usaha Perikanan di Kecamatan Cibinong, Kabupaten Bogor terdiri dari Adapun Analisis usaha pembenihan ikan konsumsi untuk 1 Rumah Tangga Perikanan (RTP) meliputi Break Even Point (BEP) sebesar Rp1.317.550; BEP Unit sebesar 905.815 ekor; Payback Period (PP) sebesar 6.5; dan Return of Investment (ROI) sebesar 15\%. Pembesaran ikan konsumsi untuk 6 Rumah Tangga Perikanan (RTP) meliputi Break Even Point (BEP) sebesar Rp2.573.814; BEP Unit: 109 Payback Period (PP) sebesar 6.1; Revenue Cost Ratio (R/C) sebesar 1.4; dan Return of Investment (ROI) sebesar $28 \%$. Sedangkan, budidaya ikan hias untuk 3 Rumah Tangga Perikanan (RTP) meliputi Break Even Point (BEP) sebesar: Rp563.100; BEP Unit sebesar 356 ekor; Payback 
Period (PP) sebesar: 3; dan Revenue Cost Ratio (R/C) sebesar 1,8; dan Return of Investment (ROI) sebesar $30 \%$ serta pengolahan hasil perikanan untuk 10 Rumah Tangga Perikanan (RTP) meiputi Break Even Point (BEP) sebesar: 2.918.126; BEP Unit sebesar 152 pcs, Payback Period (PP) sebesar 2.2; Revenue Cost Ratio (R/C) sebesar 1.4; dan Return of Investment (ROI) sebesar: $48 \%$.

2. Analisis permasalahan usaha perikanan di Kecamatan Cibinong, Kabupaten Bogor terdiri dari budidaya perikanan yang memiliki produktivitas rendah, kualitas produk olahan hasil perikanan masih kurang memadai, pendapatan pelaku usaha yang masih belum maksimal, dan dinamika kelompok usaha yang belum dapat berjalan maksimal. Keempat permasalahan tersebut dapat diselesaikan dengan menyusun rencana kerja programa penyuluhan yang akan dilaksanakan.

3. Penyusunan rencana kerja programa penyuluhan merupakan salah satu solusi dalam mengatasi permasalahan usaha perikanan di Kecamatan Cibinong, Kabupaten Bogor.

\section{Saran}

1. Usaha perikanan di Kecamatan Cibinong, Kabupaten Bogor harus didukung oleh terobosan inovasi yang mampu meningkatkan pendapatan pelaku usaha perikanan sehingga hidup mereka lebih sejahtera.

2. Penyusunan rencana kerja programa penyuluhan harus direalisasikan melalui pelaksanaan kegiatan penyuluhan di Kecamatan Cibinong, Kabupaten Bogor sehingga permasalahan yang terjadi di Kecamatan tersebut dapat segera teratasi.

\section{PERSANTUNAN}

Ucapan terima kasih disampaikan kepada Kepala Dinas Perikanan dan Peternakan Kabupaten Bogor, Provinsi Jawa Barat beserta jajarannya, Penyuluh Perikanan PNS dan Penyuluh Perikanan Bantu (PPB) Kabupaten Bogor, Provinsi Jawa Barat serta stakeholders terkait, dan responden pelaku usaha perikanan di Kecamatan Cibinong, Kabupaten Bogor. 


\section{DAFTAR PUSTAKA}

Apriliani, Tenny, Tikkyrino Kurniawan, dan Hikmah Hikmah. 2017. “Identifikasi Permasalahan Dan Peluang Perbaikan Pengembangan Kawasan Minapolitan Di Kabupaten Gowa." Jurnal Sosial Ekonomi Kelautan dan Perikanan 6(2):115.

Choeronawati, Anggih Isti, dan Nur Rochman. 2021. "Strategi Penyuluhan Kelautan dan Perikanan Dalam Masa Pandemi Covid-19 di Kecamatan Purworejo." Abdi Insani 7(3):24755.

Dinas Perikanan dan Peternakan Kabupaten Bogor. 2019. Buku Data Perikanan 2019.

Hanan, Abdul. 2015. "Pengaruh Kedinamisan Suatu Kelompokerhadap Fungsi Kelompok ( Studi Kasus Pada Kelompok Perikanan di Kabupaten Bekasi Provinsi Jawa Barat )." 9(1):29-42.

Harmono. 2015. Manajemen Keuangan. Jakarta: PT.Bumi Aksara.
Huwoyon, Gleni Hasan, dan Rudhy Gustiano. 2013. "PENINGKATAN PRODUKTIVITAS BUDIDAYA IKAN DI LAHAN GAMBUT Gleni Hasan Huwoyon dan Rudhy Gustiano." Media Akuakultur 8(1):13.

Junita, Ita, Puspa Dewi, Tatty Yuniarti, dan Jasmine Addinda Putri. 2020. "Penerapan Cppb Pada Kelompok Pengolah dan Pemasaran Hasil Perikanan Pandawa Opat di Kecamatan Cigasong Kabupaten Majalengka." Hal. 132-41 in Prosiding Seminar Nasional Perikanan dan Kelautan ke VI, Banjar baru, 17 November 2021, Fakultas Perikanan Universitas Lambung Mangkurat.

Kustiari, Tanti, Sumardjo Sumardjo, Margono Slamet, dan Prabowo Tjitropranoto. 2017. "Pengaruh Efektivitas Penyuluhan Terhadap Kompetensi Pembudidaya Rumput Laut Polikultur Di Perairan Pantai Utara Pulau Jawa." Jurnal Sosial Ekonomi Kelautan dan Perikanan $7(1): 79$. 
Madrin Takbir, Budiyanto, Roslinda Daeng Siang. 2017. "Analisis faktor-faktor yang mempengaruhi pendapatan usaha budidaya bandeng di kecamatan laeya kabupaten konawe selatan." Jurnal Sosial Ekonomi Perikanan 2(3):189-200.

Muhammad Ramadhan, Victor, dan Agus Trilaksana. 2019. "Perkembangan Perikanan dari Budidaya Tradisional ke Budidaya Modern di Kabupaten Sampang Tahun 2003-2017." AVATARA eJournal Pendidikan Sejarah 7(2).

Mustaqim, Nurhadi Ali, dan Yenni Nuraini. 2019. "Kegiatan Penyuluhan Perikanan Di Kecamatan Gebang Kabupaten Cirebon." Buletin Jalanidhitah Sarva Jivitam 1(1):37-43.

Nurfitriana, Nia, Nunung Sabariah, dan Deni Aulia. 2020. "Penyuluhan Perikanan Budidaya (Dasar-Dasar Penyuluh Perikanan Budidaya)." (ID): Amafrad Press.

Purnomo, Wahyono, Ani Leilani, dan Nia Nurfitriana. 2018. "Penyuluhan Perikanan. 1st ed." (ID): Amafrad Press.
Putri, Jasmine Addinda, Tatty Yuniarti, Ita Junita, dan Puspa Dewi. 2019. "Analisis Permasalahan Perikanan: Strategi Penyuluhan Perikanan di Kecamatan Cigasong Kabupaten Majalengka." Jurnal Penyuluhan Perikanan dan Kelautan 13(2):149-68.

Safrida, T. Makmur, dan Hafid Fachri. 2015. "Peran Penyuluh Perikanan Dalam Pengembangan Sektor Perikanan Di Kabupaten Aceh Utara." Agrisep 16(2):17-27.

Untajana, Hanok. 2011. "Pengembangan Dinamika Kelompok Tani Melalui Kerjasama." Agricola 1(1):8-17.

Yuniarti, Tatty, Shanti Dwita Lestari, Medal Lintas Perceka, Yudi Prasetyo Handoko, Heny Budi Purnamasari, Sonny Kristianto, Sri Novalina A, Nurbety Tarigan, Sherly Ridhowati, Rufnia Ayu Afifah, Adham Prayudi, dan Mirna Zena Tuarita. 2021. Pengetahuan bahan baku perikanan. 1 ed. Medan: Yayasan Kita Menulis.

Zidhane, Mauliddyane, Tatty Yuniarti, dan Nayu Nurmalia. 2020. "Profil Sumber Daya Perikanan di Kecamatan Pemalang Kabupaten Pemalang Provinsi Jawa Tengah." Jurnal Penyuluhan Perikanan dan Kelautan 14(1):73-92. 